\title{
The More Things Change, The More They Stay the Same: The Challenge of Identity for Native Students in Canada
}

\author{
Tracy Friedel \\ University of British Columbia \\ Tracy.friedel@ubc.ca
}

\begin{abstract}
For nearly four decades now, the institutional response to fulfilling the goals of Indigenous cultural revitalization, and addressing the education gap between Aboriginal and non-Aboriginal learners, has relied heavily on a theory of cultural discontinuity. While the enacting of Indigenous culture in educational realms is promoted as a solution to uneven outcomes, and as socially just in general, in-depth examinations of the effects of this emphasis tend to be sparse. This paper elucidates one such analysis, in the process offering a representation of a more or less typical group of urban Native youth; in this case, a group desirous of belonging in an Indigenous sense and highly contemplative about what that has meant for them on an everyday basis. The analysis offered here argues for further consideration of existing solutions in the complicated, complex terrain that is Indigenous education. Rather than proceed along a trajectory whereby Indigenous students are understood as 'the problem', resulting in the application of a highly problematic focus on culture, needed at this time is a serious examination of the troublesome realities of cultural fundamentalism and authenticity in Indigenous education, and the manner in which these serve to cover over critical matters concerning race and power.
\end{abstract}

\section{Background \& Methodology}

An important foundation for thinking about Indigenous curriculum and pedagogy are the important linkages between identity and place, connections that have, in many ways, been effaced by the structures and processes of Western-oriented schooling (Barnhardt \& Kawagley, 2005; Kuokannen, 2007). The lack of incoherency between increasingly place-less schools and Indigenous, place-based knowledges was an early prompt for the learning program upon which this research is based. The study involved ten urban Indigenous youth in a summer/fall non-formal, place based learning program situated within, and outside of, a large prairie city ${ }^{1}$. The growing body of literature associated with place-based learning (Gruenewald, 2003), together with understandings of place as known by Indigenous Elders and academics (Kawagley \& Barnhardt, 1999),

\footnotetext{
${ }^{1}$ The creation of the four-week program involved two urban Aboriginal organizations, one a representative group for Métis. In addition to Metis contributions, funding support was provided by Canadian Heritage's Urban Multi-Purpose Aboriginal Youth Centres Initiative and the Aboriginal Capacity and Development Research Environments program. In part, levels of grant funding determined the decision to select ten youth for participation. Youth in this study, aged 14 to 16 years, are of Cree (Nêhiyawak), Iroquois-Cree, Cree-Métis, Métis, and/or Blackfoot (Piikáni) ancestry.
}

Cultural and Pedagogical Inquiry, 2010, 1(2), pp.22-45

ISSN 1916-3460 @ 2010 University of Alberta

http://ejournals.library.ualberta.ca/index.php/cpi/index 
informed the creation of a program that sought to teach at the intersection of culture and nature.

The study was designed to be descriptive and flexible, to make certain that urban Indigenous youths' understandings were central to the research and to ensure the pliability necessary for fulfilling the original research intent. I used conventional methods associated with qualitative research, participant observation (Angrosino \& May de Perez, 2003) and interviews (Denzin \& Lincoln, 1996; Harper, 2002), as well as an approach that aimed to make youths' voice more central to the study. Critical race theory (CRT) in qualitative research (Parker \& Lynn, 2002), and its concern with educational practice and actions, resonates to some extent with Indigenous epistemologies in that, as Deloria, Jr. (2004) describes, all knowledge must begin with experience, all conclusions must be verified in the empirical world. In this article, I've employed a thematic analysis to talk about youths' experience and understanding of Indigenous identity and follow this up with a broader discussion of Indigenous identity as it relates to education, cultural politics and the reality of ongoing racism in Canada.

\section{'Trying to Overcome It': The Reality of Race in a Canadian Prairie City}

Playing outdoors on the program's first day, a game of chase involving blindfolds, I heard one youth shout excitedly to another, a male participant who was struggling to catch anyone: "Aren't you a Native ${ }^{2}$ ? Just listen!" (Descriptive field notes, July 26, 2006). Another comment I often heard during those first few heady days of place-based learning was: "We're Indians!" (Descriptive field notes, July 27, 2006). Ladson-Billings (2003) argues that, what racialized people have in common is the experience of a racialized identity; therefore, in addition to sharing political/legal and perhaps also cultural understandings, youths' identification with each other can be seen to involve common experiences that they share as outsiders and Others. As a result, youths' identity pronouncements, and related comments made during formal interviews, can be seen as reflective of not only their ancestry and geography, but also of their experience as racialized bodies in an era of ongoing colonialism. The constructed image of 'Native', a performative sign used to facilitate historical dispossession and to frame Indigenous lives as ones of depravity, contrasts sharply with how many Indigenous people understand themselves today. Yet, at the same time, prominent aspects of Indigenous identity continue to be produced extraneously, by others, in a process that renders contemporary Indigenous people virtually invisible in any other way.

The racial idiom through which a Native Other is brought to light bespeaks a collective nineteenth century European racial ideology. The twenty-first century upholding of constructions and stereotypes whose insidious roots lie deep in the Western mind is made plainly evident through the shared comments of young people in this study, for example:

\footnotetext{
${ }^{2}$ Native is a way that participants consistently describe their sense of Indigenous identity thus I use it here as part of privileging youths' voice. Also important to note is Indigenous Hawaiian scholar Kay Trask's (1996) interpretation of this term as a political statement, an indicator of Native peoples' sense of affiliation with a pre-conquest geography.
}

[Type text] 
If you say 'Oh yeah, I'm Native' they [non-Native kids] say 'Oh, my gosh - were you in a gang once?' Or, 'Is your uncle in jail? (Jae)

While there is much variance today among non-Indigenous people in terms of how the descendants of Canada's original inhabitants are viewed, Berkhofer (1978) highlights that: "the essence of the White image of the Indian has been the definition of Native Americans in fact and fancy as a separate and single other" (p. 3). Furniss (1999) argues that the conventional racist image of the inferior Indian Other, by virtue of its ubiquity in the social landscape, is a dominant discourse underlying the contemporary social relationship between Indigenous peoples and Euro-White ${ }^{3}$ Canadians. Indigenous peoples perceived of as inferior, as gang members or criminals, are part of a long, fluid history of White representations of Native people:

With the ebb and flow of cultural images of who we are [in this case, we being White, dominant society], so the image of the Indian changes - now becoming everything we fear, in the person of the marauding, hellish savage, then becoming everything we envy, in the person of the peaceful, mythical, spiritual guardian of the land who is [now] in vogue. (Bird, 1996, p. 3)

Contemporary representations of Native youth on the Canadian prairies, while produced in ways that perhaps differs from earlier constructions, remains closely tied to a mythology originating in colonial times; in particular, the myth of the noble/ignoble savage (Berkhofer, 1978; Francis, 1992). On the one hand, Native youth depicted as victims of cultural discontinuity, highly suicidal, academically and otherwise 'at-risk' amidst the chaos that is Western progress, is a romanticized image that can be linked back to the work of salvage ethnography ${ }^{4}$ and its influence in creating the nineteenth century 'noble savage'. On the other hand, the intense pathologizing of Native peoples generally (Brasfield, 2009), evident in policy discourses and portrayals of Native youth as antisocial, deviant criminals with a propensity for violence and gang involvement, conjures up an image of them as 'ignoble' beings, individuals deserving of little empathy but much surveillance from dominant society.

Dei (2007), for one, advocates understanding the emerging question of youth violence in Canada, and the perverse representations of black or Native cultures by police and media, as the application of the age old colonial framework that has characterized all European-colonial encounters. With respect to youth crime, Dei argues that institutional forces serve to juxtapose the "evils/transgressions/criminality" of black/brown bodies with the "benevolence/goodness/morality and humanity of white bodies" (p. 59). Thus, we can view the increasing media visibility of Native gangs on the prairies not so much as a reflection of reality, but in terms of how dominant systems of racialized power construct ideas about criminality, how Native gangs become racial bodies invested with a biological propensity towards violence and crime. Bird (1996) highlights that although

\footnotetext{
${ }^{3}$ At times I employ the term White, or Euro-White, to refer to colonizers/migrants (Moreton-Robinson, 2000) because it reflects an ongoing reality regarding the dominant and privileged position of White people and institutions in Canadian society.

${ }^{4}$ Franz Boas is an example of an ethnographer trained in salvage ethnography, concerned with the practice of salvaging a record of what was left of a culture before it disappears (Hitchens, 1994).
}

[Type text] 
"words like 'savage' have disappeared and the messages are more subtle" (p. 10), what is clear is that "White culture seems to feel angry at Indians who do not fit the romantic mold" (p. 4). Such anger is enacted in media because, as Bird points out, "the ability to define imagery is [itself] a consequence of power" (p. 6).

While purportedly far removed from colonizing practices, Native youth are encouraged to take up the mythology of the noble/ignoble savage, made clear in this comment by a First Nation youth, a former resident of a reserve community who, at the time of the study, was living in the city: "Some of them [Native youth] I think of in gangs but then sometimes when I think of Native youth I think of traditional dancers" (Bee). Invariably, in the presence of ongoing colonization and unfettered visual culture, White constructions of Native people have influence over how Native youth 'see' themselves. But the representations mentioned by this youth also produce opposition at the informal, interpersonal level; for example, "a rich humor that plays on and subverts dominant stereotypes, mock[s] White attitudes, federal agencies and so on" (Bird, 1996, p. 6). This resistance was observable during the time spent in the place-based learning program. Overall, however, such opposition has limited impact on substantively altering the perverse images propagated by dominant society, productions that, to a lesser or greater extent, frame how Native youth can experience the world. Thus, while youth in this study expressed animated recognition of their being Native, evident in the excited cries I heard on the program's first day, also made clear in what they say is that to an underdetermined degree, this identity comes with a cost.

\section{Indigenous Identity as a Racialized Identity}

In a focus group interview early in the study, I asked two questions related to identity: "How would you describe yourself?" and "What does it mean to you to be Indigenous?" Responses to the first question included descriptors such as "energetic" and "serious" (Jae), "hyperactive" and "individual" (Eli), "a neat freak" (Ina), "spontaneous" (Heb), "unique" and "creative" (Ger), "athletic" (Ali), and "[someone with] high expectations" (Fay). Responses to the second question were much different. I had expected youth to talk about their relations, experiences that had some connection with the objectives of the place-based learning program. Youth alluded instead to their experience of Indigenous identity in terms of a connection to racialized stereotypes and racism; for instance: "This one kid in my school, he always used to say that Natives were all drunks and stuff and that always made me really mad." (Day)

Youths' talk of racialization and racism in a non-formal place-based learning program is perhaps testimony to the lack of opportunity afforded them by educational or other institutions to openly discussing the ongoing prevalence of race in Canadian society (Dei, 2007; St. Denis, 2007, Razack, 1998). In an ethnographic study involving Navajo youth, Deyhle (1995) found that students who "attempt to make racial discrimination visible within the school have been silenced by the Anglo students and school administrators" (p. 10). Canada can be seen to differ little in this regard; in an ethnographic study focused on the community of Williams Lake in British Columbia, the historian Furniss (1999) found that students and their families regularly reported racial discrimination yet few teachers or administrators saw this as an issue for Aboriginal students.

[Type text] 
Given that racialization and racism took unexpected centre stage on just the second program day, and in light of having observed youths' own 'race talk' from our first day together, in the next interview I inquired further into their experience with racialized stereotypes. In total, nine out of ten youth highlighted racialization as an important issue; in addition to the comment made by Day above, youth shared these thoughts on the subject:

People think that most Natives ... most of my friends think that Natives are drunks because if you walk downtown, most of them are Native. And stoners and stuff like that. It's just trying to overcome that. Ignoring it, finding different ways to get over it. (Ali)

In my last foster home, they used to see Natives on the side of the road drinking a beer or something and they said, 'All Natives are like that.' That's when they used to try and tell me that I'm not Native but I knew I was, and I knew that all Natives weren't like that. That's, like, ignorant right there. (Eli)

I remember when I was in grade four, my [non-Native] friend and me were standing outside after school; she was waiting to get picked up by her dad. We had an argument about races and stuff like that ... we started throwing words at each other and then she's like, "My dad was right, you guys are all the same. (Ina)

They kind of look at us like we're [Native people] all drunks and it really bugs me because not all of us are and most people who drink - I guess they just feel bad for themselves and stuff like that and they're trying to help themselves. (Ina)

In one of the schools my cousin went to, he and his cousin were the only Natives and it was a racist school. Some kids vandalized the door and wrote 'Native power' on it ... they [my cousin and his cousin] were blamed because they were the only two Natives that went to that school and they got kicked out for it. (Bee)

When sitting in a group of White kids, not being racist or anything, and you bring up a powwow, they' $\mathrm{d}$ be like 'What is that? Is that where a whole bunch of gangs go?' (Heb)

[Stereotypes] kind of bother me sometimes. It seems the only thing that people hear about is that there are gangs and they're bad and all of that stuff. All you hear is the bad stuff. You don't hear about the people who are good and are doing good stuff, and it bothers me. (Jae)

The drunk stereotype downtown - I think it makes me more angry because we were exposed to alcohol in the past and it makes no sense them blaming us now. I feel kind of sorry for them because I think they' re victims of racism or, a capitalist society we live in and we are not that financially rich. (Ger) 
Being Aboriginal ... [it's] kind of hard just on a social level because you're looked down upon or you have to prove yourself because from the get-go, you're lower than them [non-Native society]. That's how I feel that I'm looked at. (Fay)

The persistence of dehumanizing stereotypes, created in past eras and propagated in one form or another today, serve to reinforce racial and material domination. Arising in the context of colonial discourse, Duran (1996) describes the 'Drunken Indian' stereotype as an overloaded and over determined sign, an understanding of 'Indian' as, "a stage in a social evolutionary ladder, the embodiment of a genetic wholism or degeneracy, a psychological archetype or a shadow projection of an entire continent" (p. 111). In an analysis of Aboriginal/non-Aboriginal relations, Furniss finds that one of the most common imposed negative identities is that of the 'drunk Indian': "The weight of [such] stereotypes is felt as a physical burden, as something that Aboriginal people have to 'pack' around, as an image that precedes them in their interactions with non-Aboriginal people" (p. 130).

Keeping in mind that youths' comments arose in response to a query about Indigenous identity, it seems appropriate to think of these in relation to arguments put forth by Omi \& Winant (2005) in the U.S.; that is to say, in Canada, race is a "relatively impermeable part of our identities" (p. 5). While the matter of identity for marginalized people proves intricately complex; as Omi \& Winant make clear, the process of racialization greatly diminishes such complexity, making the Other much easier to comprehend.

In talking about his experience with racism as an urban Native youth, one 14-year old First Nation male points to the historical roots of the 'drunk Indian' stereotype:

... some bad racist things that have happened in the past like alcohol that was presented to us which, kind of mostly, in my opinion, and which I also learned from my mom and dad, kind of destroyed most of our culture ... the White people were racist to us because we were different. (Ger)

As part of colonization and White encroachment in North America, alcohol was used by White explorers and traders with "the most deceitful tactics to make large profits" (Duran, 1996, p. 116) but alcohol was also important in efforts to dispossess Native people of land and resources, all the while solidifying a belief in Native peoples as 'savages', far below the reaches of European civilization. The ongoing discourse of Native people as drunks and inferior perpetuates inequalities in Canadian society: "conventional forms of racist beliefs and practices have served as effective modes of power that over the long term have maintained the subordinate position of Aboriginal peoples" (p. 137).

What is also interesting to note in Ger's statement about alcohol's impact on culture is his reference to the past, "bad, racist things that have happened in the past" (my italics). In part, this statement reflects a curricular practice that relegates racism to history (Schick \& St. Denis, 2005) and propagates a national identity that, while on the surface seemingly fair, serves to produce and maintain groups who are culturally inferior and culturally superior in the Canadian context. The celebration of tolerance and diversity, both foundational to Canada's constructed national identity, serves to ignore deny present 
day racism, suggesting that "even if Canadians were horrible in the past, the nation is now making up for it" (Mackey, 1999/2002, p. 100). Eli alludes to such tolerance when articulating what he learned through the summer place-based learning program:

[I learned] tolerance for ignorant people (my italics)... because I noticed a lot of people [on the street] were giving me looks; because the looks say, they didn't know me. They were just being ignorant ... even when we were walking to some places, I could just see the looks they were giving me, just sort of ignorant.

At times during research interviews, three youth intimated that racism was not something they had directly experienced:

... different skin color, how you act, what you say. At school, some kids are pretty racist and they just call people names and all that. I never really got called names yet, but I've heard people ... (Con)

It doesn't really affect me that much because I don't look Native. (Bee)

I don't really look that Native, and I don't go to powwows all that often, actually, ever. So it's not like 'Yeah, I just came back from a powwow this weekend', and there's not really a lot of chance they will ask me and I will tell them. (Jae)

Of note among these comments is that, at other times during the course of the place-based learning program, two of these youth had described racist experiences involving them personally, situations where racist acts had targeted them. This contradiction can be interpreted in a couple of ways; first, as recognition that: "The racial invisibility and the ability of some Aboriginal people to 'pass' as white often results in different experiences and relations to racist practices" (St. Denis \& Hampton, 2002, p. 15), and second, that racism regularly escapes scrutiny because, more often than not, it is restricted to "de facto examples of racism that warrant public outrage" (Schick \& St. Denis, 2005, p. 304) ${ }^{5}$. These statements made by these three youth reflects the reality that: "Ironically, those who must bear the effects of racism and white supremacy may also deny and/or avoid the problem of racism" (St. Denis \& Hampton, 2002, p. 6). Yet, while youth at times denied racism, they also made clear that racism is something that continues to be experienced by Native people and that 'passing' for White can mean being able to avoid, at least in a direct way, some of the worst experiences.

Encouraging Native youth to understand their problems as tied to the past, or to far away places, as regularly happens in schools, rather than as occurrences of everyday racism, denies the power relations on which racial privilege and inequality depend. Such denial can be seen to lie at the heart of Canada's national narrative, a story in which marginalization and difference is taken as given rather than as productions of unequal social relations (Schick \& St. Denis, 2005). One of the individuals who had disavowed personal experience with racism, had on another occasion explained that 'being' Native was about living as a minority among others who have little understanding of who he is:

\footnotetext{
${ }^{5}$ These scholars cite apartheid in South Africa, the Holocaust in Germany, and slavery in the U.S. as examples of the racism and genocide that does get attention in schools.
}

[Type text] 
“There's not a lot of Native/Aboriginal [people] and they [non-Native people] just think you're different and how they look at you ..." (Con). His sentence trails off, and after a short time he continues "... different skin color, how you act, what you say". Similar to other youth in the study, he is aware that as a Native person, he is constructed as racially different. A slightly older male youth also talks about how he feels he is seen:

I can tell by just the way people look at me and look at the other kids in the group, sometimes I'd get a long stare or glare, or by occasional people, a tilt of the hat, by the people that the other kids would call gangsters. (Eli)

The notion of being 'looked at' (hooks, 1992), alluded to by a number of youth, is important given that:

Status domination operates through shaming, the humiliation, and the denial of worth communicated in a variety of subtle and habitual practices: sharp glances, passing remarks, turned backs, verbal insults. These interpersonal modes of power and violence, when practiced over a long term against a population already made vulnerable through other modes of domination, have a profoundly demoralizing impact. (Furniss, 1999, p. 132)

Also important in Eli's statement is his reference to being affiliated with groups labeled 'gangstas'. In having formed relations with such groups, Eli can be thought of as involved in a process of identity creation meant to help him survive the conflicts and tensions of the lower income, racially differentiated neighborhood where he lives:

I can dress other ways to make it look like I'm not so tough but...its sort of a matter of survival down in my area. Because I always got beat up when I was dressing preppy ... some people think that because of the way I dress it doesn't mean that I'm necessarily smart so I always prove people wrong about that. So I think that's another thing that stands out. People say I'm rather quite bright. (Eli)

Dillabough, Kennelly \& Wang (2005) argue that subcultures exist in all economic classes; however, taking on a persona such as a 'gangsta' can occur for reasons concerning the need for both class and race protection. Eli's inner city neighborhood, itself a product of a class and race-based society, was frequently mentioned in interviews and informal talk, for example:

[Where I live] you can hear people fighting every day, every night. At one certain time of night, there's lots of police. They're around there all the time. You kind of get used to it after while. (Eli)

Affiliating with particular subcultures as a means of coping with tensions tied to class and race, while perhaps necessary, does little to disrupt the discursive stereotypes that youth in this study describe. Sustained through circulating colonial/post-colonial imagery, popular culture, curricular expressions, national narratives, etc., these stereotypes produce not only material, but also psychological effects.

[Type text] 


\section{The Challenge to 'Fit In' as a Racialized Subject}

The inferior status conferred on Native people, one that every youth alluded to in one or another, has not disappeared despite significant public sympathy and the multicultural policies of the past four decades. Contrary to the notion of raceless-ness propagated by Canadian multicultural discourse, what is made plain is that Native youth continue to experience a particularly demonizing racial signification in the consciousness of dominant society. Such signification has undeniably injurious impact, alluded to by comments such as these:

[Racism] hurts. Because it feels like you're doing something wrong when you know it's the other person, the racist person, saying it - not you. It's not your fault. (Ina)

I think if someone tries to be racist to me, just be better than them and you won't have to fight them. You're just proving them wrong. (Ina)

If you're a Native person, you're automatically looked down upon; I found this in any school that I went to. So their expectations are lower for you. (Fay)

I have been [a victim of racism] before. Usually people don't say anything but as soon as you say you are Native, they're like 'Oh, an outsider'. (Fay)

You have a lot of racism in your life and you can either fall one way, which is being really racist yourself. Or you could be really accepting of others, because you are a minority. It's scary. (Fay)

In grade six, all the boys picked on me, being racist because I'm Aboriginal. They kept on saying we're dumb, we're useless; we're a whole bunch of things. [It] kind of hurt inside but I tried to tolerate that because, I was like, 'Why would someone think something so mean?' Then I came to realize that racism is a thing we may deal with. (Ger)

I got in trouble for apparently stealing twenty bucks off the teacher's desk and I emptied out my pockets and she even checked my socks and everything, my hat brim. I'm like 'It's because I'm Native, isn't it?' (Eli)

In elementary school, I was a big loser just because I was Native. (Ali)

[People are] meaner to you just because you're Native but there are some advantages because people say we were here before them so it's just like it's our land, and I like saying it's my land and I came from here. (Heb)

[Type text] 
I get along better with Natives because, in my school [mostly non-Native students], I don't even talk in my classes. Most of the Natives are off, by themselves. Or, like, they're just the tail end of groups. (Ali)

Dei (2007) contends that relations of domination are shaped, in part, by local actions and daily discursive practices. The last comment which points to a self-regulated invisibility, and that describes Native youth as being "the tail end of groups" (Ali) can be understood in the context of Brayboy's (2004) analysis of the strategies that Native Americans in institutions of higher education use to make themselves invisible. As Brayboy describes, these strategies are invoked because of the problematic way that Native Americans continue to be seen in the U.S., in ways that contribute to their marginalization, surveillance and oppression ${ }^{6}$. Also useful for understanding how this youth describes the negotiation of educational space is Furniss' (1999) argument regarding the hyperinvisibility of Aboriginal people in the public landscape. Achieved through avoiding eye contact with Native people, along with other subtle mechanisms of exclusion, Furniss argues that hyperinvisibility brings with it a form of physical subservience. While Furniss writes specifically in relation to a small, interior British Columbia city, the individual making this comment describes that, at least for her, a similar reality holds true on the Canadian prairies.

Chartrand's (1992) description of racism is helpful for understanding its intersection with power in a Canadian prairie city:

Racism is always present in a situation where there is an imbalance of power which permits the 'racist' behaviour to have effect. The racist comments of a white, Anglo-Saxon child in a schoolyard in Winnipeg, if directed at a young Cree, are liable to have effect because the Cree are vulnerable to the power of non-Aboriginal people in Winnipeg. That is, the Cree yield relatively little clout in the economic, social, and political life of the Winnipeg community. On the other hand, the racist taunts of a young Cree directed against non-Aboriginal schoolyard acquaintances in a Winnipeg suburb are hardly likely to have a similar impact on the White Anglo-Saxon recipient. Racism only matters if it has the power to hurt. (as cited in St. Denis \& Hampton, 2002, p. 10-11)

As can be seen by youths' comments, 'fitting in, ${ }^{7}$ with dominant White culture means developing different strategies to cope with racism fueled by power. Fay, on the one hand, says that she avoids racism, at times, by denying an Aboriginal identity:

Some people ask me if I'm Filipino or Spanish; and some jokes I hear, it's really bad. Sometime I have this mask and I don't want to say anything like 'Shut up' or, 'I'm Native', because that's [being Native] not a good thing.

\footnotetext{
${ }^{6}$ See also Young (1990) who argues that minoritized groups "undergo a paradoxical oppression, in that they are both marked out by stereotypes [as different] and at the same time rendered invisible" (p. 59).

7 'Fitting in' is also at play in an ethnographic study in the U.S. northwest where Marker (2004/05) examines the experience of Lummi high school students during the 1970's.
}

[Type text] 
Ger, on the other hand, says: "I tried to tolerate it [racism] because ... I came to realize racism is a thing we may deal with." Ina shares that Native youth need to overcome stereotypes through individual merit or personal achievement: "[I] try to show them [nonNative people] that you can do stuff that they think that you can't." Ali similarly makes reference to the need to continually prove her self: "[Non-Native] people think they' re better than you ... I think you're always having to compete." Eli describes fitting in as involving being hyper-conscious about where he is at all times: "You [Native youth] can't go in certain areas."

When it comes to 'fitting in' in Western Canadian society, these youth find themselves in a similar position to those exiting residential schools in the late nineteenth/early twentieth centuries; despite their efforts to become educated, sometimes in inhumane conditions, opportunities to flourish both inside the school (Barman, 2003) and later, in non-Native society (Miller, 1996), were lacking. Individuals attending residential schools were often unable to contribute on their own terms, or on anyone else's, within dominant society; for instance, many were unable to secure jobs due to the school system's systemic flaws as a result of racist attitudes in Euro-Canadian society generally. However, Miller (1996) also points out that some of these same students also experienced difficulties 'fitting in' in their home communities, due to loss of language or the long separation from home. Such challenges to 'fitting in' persist today; Heb refers to the effects of language loss on her sense of belonging as a Cree-Métis person:

When you go to a gathering, they're all talking Cree to each other and it's just like you want to get into the conversation but you don't know how, and it makes you feel like you're kind of like an outsider.

Fay makes evident that for her, being Cree is a powerful, double-edged sword:

You have so many negatives you kind of see [being Cree] as a negative thing so its more of a burden than a strength or a potential strength; you grow to hate it and because you hate that part of you, you just hate more of yourself. It just seems like one more thing; you have trouble with friends and it's just one more thing that's piled on that (Fay).

Such sentiments correspond with what Deyhle (1998) found in her work involving Navajo students; that youth striving to achieve on the terms of the dominant society, terms that can be unavailable to them due either to poverty and/or to various forms of racism, also often struggle to achieve on the terms of their own community, to meet the expectations by others that they will know their culture and language. As Deyhle argues, this leaves young Native people "in a deficit, no-win position" (p. 6).

It is highly problematic for Native youth to be led to understand racism as constitutive of a bygone era ("in the past"), as inevitable ("I think if you are exposed to [racism] you learn to tolerate and withstand [it] ... I think it makes us more immune to it") or as only about skin color ("Racism is all about the same thing. It's about color differences"). An educational focus on culture, while ignoring everyday racism, means that, among other things, racism's psychological implications are denied: "Racism hurts. Like their culture is better than ours. You start believing it and then you start feeling 
really low." (Ali) St. Denis \& Hampton (2002) identify internalized racism as one of the major effects of racism for Aboriginal students in Canada, resulting in low self-esteem, very often the focus of educational initiatives rather than the racism that produces this condition. The focus on culture (and not race) evident in schools over the past several decades can be seen as promoting an understanding of Native oppression as the effects of cultural difference; for instance, in this comment, "their culture is better than ours" (Ali). This emphasis in education and beyond has many unintended effects for Native youth.

\section{The Legacy of Multiculturalism for Indigenous Students}

When describing what it means to be Indigenous; that is, how they see themselves as Indigenous persons, in addition to raising the issue of race, a number of youth placed 'culture' in the foreground:

You can always find out more about yourself no matter how old you are; you can look back on your own culture and learn all the different things and help with your identity. Like how you feel about yourself and everything (Jae).

In addition to referring to a connection between Indigenous identity and self-esteem, Jae refers to culture in a historicized way: "You can look back on your own culture" (my italics). Others, such as Eli, talked about culture in ways that link to colonial oppression: "How it [culture] got stolen from us." Since the 1970's, an era that saw enhanced institutionalization of social justice in Canada, fostering Indigenous identity has played out through a focus on cultural revitalization. A significant volume of research concerning Native learners has aligned with this focus on cultural revitalization; specifically, the need to overcome discontinuities between the culture of the mainstream school and the culture of the Aboriginal/Native American home ${ }^{8}$. Yet, some researchers, among them St. Denis, Bouvier \& Battiste (1998), have argued the need to "scrutinize and understand the limits of cultural difference approaches which may inadvertently further stereotype peoples" (as cited in St. Denis \& Hampton, 2002, p. 32). These scholars are concerned with a denial of ongoing oppression for Native students and the tendency of schools to emphasize superficial notions of Indigenous culture. Youth burdened by racialized stereotypes, yet expected to know their culture, or at least some shallow, decaying version of it, are provided very little help in terms of coping with everyday racism. Deyhle (1998) describes such scenario as one that leaves youth in a difficult situation, basically ignoring "what is done to the individual in a racially charged community" (p. 6).

\footnotetext{
${ }^{8}$ Understanding cultural disjuncture, between the homes of Native students' and the dominant culture of the school, as leading to conflicts, misunderstandings and, ultimately, failure for some students (Ledlow, 1992), has prompted initiatives aimed at making education more culturally appropriate (Royal Commission on Aboriginal Peoples, 1996).
}

[Type text] 


\section{The Problem of Cultural Fundamentalism}

If you go look for your culture and its obsolete because no one was trying to keep it alive ... you feel ashamed because you don't know it [culture] and you're letting them down. My social studies teacher was Native and he was like, 'You guys, do you know about your culture?' I'm like, 'No.' He said, 'Exactly! (Jae) ${ }^{9}$

In an interview at the start of the program, a number of youth, including the individual cited above, expressed feeling responsible to 'find' and 'know' their culture. Heb, a youth raised both within and outside of the city, states: "You move away [from the reserve] and you just go and visit once in a while and you don't really get to know it [culture]" (Heb). Bee spoke specifically about the pressure she feels to know her culture: "My parents don't even know it [culture] and they expect me to know it." Having lived on a reserve for the first half of her life, Bee discounts a connection between reserve life and knowledge of one's culture: "They [kids on the reserve] really don't know anything about their culture. I can bring up more stuff than they can even though there's powwows there, because my mom makes me go to them, to see what they do." In dispelling the notion that youth growing up on reserves may know more, this individual is in agreement with Aboriginal youth in a Winnipeg study who repudiated the reserve as a repository of culture that can aid in their identity development, even though, they at the same time they identified Elders living on-reserve as the true cultural teachers (Belanger, Barron, McKay-Turnbull \& Mill, 2003).

Given that there is a sense that culture and language are important, understanding more about this from the perspective of youth is key to understanding the pressures they describe:

[My mom's] like, 'How do you not know this [Cree language]?' And I'm like, 'How do you not know this? You lived up north for how long and your grandmother could have taught you. You lived with her.' I've tried to learn and she hasn't, and she expects me to know. Its like, 'How am I supposed to know if you don't?' (Jae)

My cousins up north, they learn Cree ... I'm really jealous of that because I wish I could learn. I've always wanted to learn but my grandparents won't teach me ... they're like, 'If you're serious, come live with us.' It makes you feel different from them [grandparents] because you don't know it and you can't talk to them. You feel like you're not part of the family. (Heb)

My mom knows it. She's [First Nation]. She was going to teach me but ... [voice trails off]. (Con)

You move somewhere else ... It's kind of weird when you go into a school and they're like 'What's your culture?' I say, 'I'm Native' and they say, 'Can you speak it?' Its like, 'No one ever taught me.' (Bee)

I'll learn the language ... and shove it in my dad's face, show I learned it. (Bee)

\footnotetext{
${ }^{9}$ See also Friedel (2010) for an analysis of this quote.
}

[Type text] 
Evident in these statements is frustration over not being able to oblige in terms of an expectation that youth will know their culture and/or language, and the blame that is assigned to parents and grandparents for this fact. The ten youth in this study, none whom can speak (or comprehend) their Indigenous ancestors' language, are among the $81 \%$ of Aboriginal youth living in Alberta who do not have knowledge of an Aboriginal language (Statistics Canada, 2008). Rather than interpret the lack of cultural transmission for what it largely is, a product of historic and ongoing colonialism and racism, and that perhaps the reason parents themselves do not know the culture and/or language is due to the desire of previous generations to ensure their children would avoid the stigmatization associated with being Native in a White supremacist society (St. Denis, 2004), youth tend to hold their parents and grandparents accountable for their now felt deficiency as Indigenous people.

In reviewing the research contributions of Bea Medicine, Deyhle \& McCarty (2007) point out that Medicine's work helped to shed light on "the ambivalent language attitudes and practices that federal education policies had left in their wake" (p. 213). Medicine's extensive examination of Native American language use in the U.S. revealed that many Native people did not want their offspring to face the same difficulties learning English that they themselves had; neither did they want their children to suffer the degradation of spirit and intellect that many parents and grandparents had experienced through the schooling process (p. 213). Native languages are invaluable, unique stores of human intellectualism; yet, in the context of ongoing oppression, it is little wonder that the number of language speakers continues to diminish. At the same time, the ability to speak a Native language increasingly serves as a cultural marker for Indigenous people, a sure way to be accepted as a Native person (St. Denis, 2004; Lawrence, 2003). It is therefore not surprising that Native youth may be angry that they do not know their language, or that Native parents may want their children to learn this. In a climate where fundamentalist ideas about culture and language flourish, Native youth become caught up in what McCarty, Romero \& Zepeda (2006) identify as a complex interplay of personal and interpersonal processes in cultural revitalization, processes that "are shaped by and shape racialized discourses and larger relations of power" (p. 42).

\section{Cultural Uncertainty and Cultural Pride}

While a number of youth described feeling pressured to know their language and culture, one spoke specifically about the responsibility he feels towards his:

It's a delicate culture and everything, and you've got to take care of it. You've got to preserve it (Eli).

When asked how he would go about preserving his culture, he responded: "To be honest, I don't really know how I would." (Eli) Despite not having a sense of how, he understands culture as something delicate, as an entity 'at-risk'. He explains further: "To me it's all about being proud of it. Being proud of the fact that you're a Native and you gotta keep the culture intact." (Eli) This paradox of cultural uncertainty and cultural pride can only be understood in the context of the particular culture-focus prevalent within 
Aboriginal education over the past several decades, an emphasis first promoted by the Canadian government. As St. Denis (2004) points out, The 1967 Hawthorne Report encouraged the development of pride and dignity as a solution to systemic problems resulting from the colonialism and racism the Canadian government had perpetrated against Aboriginal people. Aboriginal people were encouraged to turn to culture, "to accept cultural nationalism and cultural pride as solutions to systemic inequality" (St. Denis, 2004, p. 36). A focus on reclaiming a positive cultural identity, instituted in Aboriginal education for many years now, has become a mantra for Native students: 'Be proud of who you are' is a message heard often, delivered to youth everywhere including over the course of this study. This focus on promoting cultural pride without addressing the larger issue of epistemic ignorance that prevails in education (Kuokkanen, 2007) has conflicting consequences for Native youth in that, while it promises liberation, it also places the burden of 'cultural revitalization' squarely on their shoulders. In that, it minimizes a more general "analysis of how historical and contemporary practices of racial inequality limit the aspirations of Aboriginal people" (St. Denis, 2007, p. 1080).

\section{Intra-group Implications}

Youth in the study tended to downplay the existence of intra-group racial talk ${ }^{10}$; however, when asked about this during one interview, comments included:

[Being called White], I think it was her [another youth] acting White, like 'Oh, I'm going to the mall today, I'm going to buy some new shoes' and all that. I guess you can't say that if you're Native [laughs]. It's like, 'I have beef jerky and you don't.' That's Native! (Heb)

Identification as a Native person on the basis of such perceived notions of cultural difference has implications for not only Native youth, but for all those staking claim to an Indigenous identity. The focus in schools on stereotypical notions of culture, while at the same time ignoring race, produces a cultural hierarchy that serves to keep racial domination intact at the same time that it ignores pervasive social inequities (St. Denis, 2004; Green, 2004). Deloria Jr. (2004), referring to fundamentalist interpretations of Native American cultures, states that, "Indian life, culture, religion, and beliefs have become so bastardized that we have Indians interpreting their traditions as if they had missionary purpose" (p. 5). The result, argues Deloria Jr., is that "things Indian have become more fantasy than real" (p. 5). Thus, despite a spate of multicultural educational policies and a decidedly 'just' focus on revitalizing culture in Indigenous education over the past three decades, many young Native people in Canada have a limited sense of what culture means beyond its ersatz versions. Moreover, in addition to propagating imagined notions of culture, which in turn contributes to a cultural hierarchy for Indigenous people, cultural fundamentalism serves to reinvigorate the brand of authenticity that first appeared in the nineteenth century.

\footnotetext{
${ }^{10}$ For example, at times participants described each other using terms such as "Whitey", "White" and "mônîyâw", a Cree word meaning 'a White person.'
} 


\section{Authenticity and Indigenous Identity}

Related to the idea of cultural fundamentalism are authentic notions of Native 'culture'; in other words, culture as singular, as homogenized, as an essentialized object. Raibmon (2005) argues that, regarding Aboriginal peoples, the notion of authenticity should be thought of not as something 'genuine' (my italics); rather, it is an historically entrenched discourse: "a powerful and shifting set of ideas that worked in a variety of ways towards a variety of ends" (p. 3). Raibmon connects the concept of authenticity to the art world, where it is a referent with near relations such as 'real' and 'true.' With respect to Aboriginal culture, authenticity conjures up notions of an inert way of being, abstracted from everyday life and ascribed to the past. When discussing Indigenous identity or what it was like to learn from Native teachers, a number of youth (including two raised and schooled on reserve for several years) made reference to a view of Indigeneity that seems only about the past; for example, this statement from earlier: "You can always look back on your own culture and learn all the different things" (Jae).

Other comments that allude to the idea of Indigenous cultures as authentic include:

It doesn't seem like I'm Native in a way sometimes because I don't really have that many Aboriginal things. (Bee) ${ }^{11}$

You can't really learn a lot of stuff in the city. You can [learn] some but you don't really get to go into the mountains and learn a lot of the really traditional things. (Fay)

[I want] just to learn all the old ways and stuff, learn everything that we did (my italics). (Day)

Well, there's one incident at my school where this girl, she's colored, and she brought up tipi's and [said] 'Why would we have them?' This was in social class and I didn't get why she was saying that because it's our culture and we can express it the way we want but she just came out and started talking about it like it was a bad thing. Why [do] we have tipis and why [are] the reserves are so dirty and stuff like that. I'm sitting in the class wondering if she knows I'm Native, because I wouldn't want to hear that stuff. It made me feel really mad and I just kind of wanted to walk out of the class and just ... I don't want to hear that stuff, but then later I went to talk to my teacher about it and he said that won't be happening again because he didn't mean for it to happen, she just brought it up and he told her that she should watch what she's saying because she doesn't know. She should think about it first. (Heb)

Evident in the talk of Heb is not only a silencing around issues of race and colonial oppression, but a focus on stagnated notions of culture, a circumstance that can be interpreted as reflective of the work of authenticity and ideas traceable to the nineteenth century; specifically, anthropology's legitimating of the idea of authentic Indians.

${ }^{11}$ See also Friedel (2010) for an analysis of this quote.

[Type text] 
In examining Native-White encounters in the Pacific Northwest during the late nineteenth century, Raibmon (2005) describes the context that originally produced the notion of authenticity as well as its early effects:

Non-Aboriginal people employed definitions of Indian culture that limited Aboriginal claims to resources, land, and sovereignty at the same time as Aboriginal people utilized those same definitions to access the social, political, and economic means necessary for survival under colonialism (p. 3).

For Indigenous peoples in earlier colonial times, popular understandings of authentic Indian-ness had a "racial tenor, marking them as separate rather than similar [to Whites], even when absent of explicit racial references like blood quantum, halfbreed, full blood" (p. 6). The key elements of authenticity's "colonial cosmology" (p. 3) are binary markers such as Indian/White, traditional/modern, colonized/colonizer, rural/urban, static/dynamic, past/future, uncivilized/civilized, nature/society, cultural/political, feminine/masculine, collective/individual, etc. In all of these things, Indians as authentic are the opposing image of a powerful, White male colonizer.

This binary system, instituted in part through the historic cataloguing, categorizing, and displaying of a Native Other (Edwards, 1992), reverberates in the twenty first century through Canada's liberal multicultural discourse (Friedel, 2010). The imperialist nostalgia associated with authenticity (Raibmon, 2005) is perpetuated through educational programming that focuses on shallow notions of culture; for example, that which Ojibwa scholar Hermes (2005) writes against:

Teaching beadwork or Native dance without a deeper cultural context can intersect with mainstream stereotypes and students' notions of equating a Native identity with these traditions. (p. 10)

On the issue of authenticity, Thomas King (2003) describes this as "a racial reality game that contemporary Native people are forced to play" (p. 55). Two youth in this study lend much credence to King's assertion:

Sometimes when I tell people I'm Native, they're like, 'Oh, you're Native.' And then they ask me why I'm not on the reserve, and it's like 'My mom doesn't like the housing.' They're like, 'Oh.' (Bee)

Sometimes youthful people will actually start fights and everything and just because I'm Native doesn't mean I know how to fight real well. I don't really know how to fight that good. (Eli)

The focus on simplistic and/or problematic notions of cultural difference contributes to authenticating Indigeneity, producing what Deloria Jr. (2004) alludes to as "bastardized" expressions of traditions or what Kuokkanen (2007) describes as "sanctioned ignorance". Kuokkanen (2007) highlights that such an emphasis on culture covers over racial and power inequities while leaving colonial structures unaddressed. This means that the racism Native youth experience, including that which may lead to their departure from the school, or to the voluntary forming of small-knit youth communities, is ignored 
(Huffman, 1991). Ledlow (1992) contends that race is important for looking at issues in Native education because "even proper application of culturally relevant curricula and pedagogy may have only limited value in terms of explaining Native student attrition" ( $p$. 21). ${ }^{12}$

In a recent study examining Aboriginal youths' sense of belonging in the city of Saskatoon, MacKay (2005) raises a number of issues relevant for thinking about the experience of Indigenous identity for urban Native youth today:

Identity may be a topic that has gone out of fashion in academic circles, but each subsequent generation of Aboriginal youth who live in an urban centre must come to terms with it on an individual basis. As youth, they must gain an intimate understanding of who they are as individual beings, and they must gain the recognition of a community of people to affirm their belonging. Youths' sense of self as belonging to a collective is vulnerable to many influences that can undermine their sense of identity and self worth. The shared experiences of real or assumed poverty, racism, and victimization can lead a person to resign oneself to this plight or to reject belonging. Societal attitudes that dismiss contemporary or adapted Aboriginal cultural expressions as less authentic, non-traditional, or unworthy weaken individual and collective identity (p. 7).

Understanding identity as, at least in part, a transactional construct, and not a fully inherent sense of one's selfhood, Furniss' (1999) research in a small city in British Columbia makes clear the importance of the dynamic of power for thinking about issues concerning Indigenous identity:

Today, the most common sites of face-to-face interaction occur in the city's businesses, stores, schools, and government agencies in which Aboriginal people are consumers of goods and services offered largely by non-Aboriginal providers. These providers may 'know' about Aboriginal people through the anecdotes and jokes exchanged during conversational rituals but perhaps not through personal relationships with them. As a result, when an Aboriginal person enters a store, an office, or a school classroom, his or her Indian-ness - and the assumptions that accompany that designation - may predetermine the manner in which the provider relates to him or her. (p. 124-25) ${ }^{13}$

Youth in this study make clear that the racism they experience in encounters with nonIndigenous people is an emotionally and psychologically crushing experience: "It hurts." Yet, at the same time, youth are ready to bear the burden of keeping their cultures intact, even as the discourses making up cultural revitalization construct them as culturally disconnected. However, beyond the superficiality of culture in schools, and an insatiable desire to know the Other, we shouldn't entirely discount the idea that Native youths'

\footnotetext{
${ }^{12}$ See Friedel (2010) for a broader discussion of racism and early school leaving.

${ }^{13}$ See also the Urban Aboriginal Peoples Survey (2010), a large scale study which found that a significant number of Aboriginal people say their experience with non-Aboriginal services was negative because of racism or discrimination (p. 84).
}

[Type text] 
desire to belong in a genuinely Indigenous sense stems from their awareness that in the past:

Following traditional practices like their ancestors enabled Indian people to be protected from evil, including evil powers of the supernatural. Dedication to the "good" life of following cultural norms even during hardship corroborated that the ancestors were right and that traditions should not be questioned. This inertia of continuity provided security between the people, compelling them to depend on maintaining traditions. (Fixico, 2003, p. 53)

Similar to what Raibmon (2005) uncovers on the northwest coast in the nineteenth century, Native youth in this study are torn between clan obligations that hold out hope for much good, and a desire for dignity, acceptance and equality in society more broadly.

\section{Re-thinking the turn to culture}

The focus on culture in Aboriginal education, a break after more than a century of policy interventions aimed at so-called 'civilizing the Indian', can be thought of as an iteration, or recursion, of the perennial problematizing of Aboriginal education in Canada. There has certainly been modest advances in educational and political terms since the 1970's; however, continuing to understand Indigenous youth as disconnected from their culture, as 'culturally lost', is "a benign way to describe the effects of the discrimination, exclusion and sustained violence and aggression they face on a daily basis" (p. 43). In this sense, Native youth are burdened not just by race, but also by culture. The pressures of authenticity, which demands of Indigenous peoples that they be unequal collaborators in the discourse (Raibmon, 2005), leads to subverting rather than furthering long term Indigenous aspirations. As Hermes (2005) explains in relation to Native American education, "the notion of differences between cultures alone is an inadequate explanation for failure" (p. 22); needed is a more effective theory, one that includes a focus on economic oppression. Situating not only class, but race, gender, epistemology and other bases of oppression at the center of Indigenous research is necessary to thwart damaging discourses that prevail in Canada, and to create the space for engaging genuine Indigenous paradigms in educational realms.

Youths' sharing of stories concerning racialized oppression and cultural pressures contributes something invaluable to our understanding of not only how racism impacts Native youth in Canada, but also of the shortcomings of the existing cultural difference approach as the solution to social, political, economic, and epistemic inequities. Rather than focus on culture as the answer to myriad problems in education, culture in this case being colonial knowledge about the Native Other, I join St. Denis (2004), Hermes (2005), Kaomea (2000), Kuokkanen (2007), Brayboy (2004), Deyhle (1998), Huffman (1992), Ledlow (1991) and others in arguing for an analysis of how marginalization, exclusion, surveillance and oppression is enacted for Indigenous students in educational realms and beyond. This demands an examination of the practices of Whiteness and ongoing colonialism in producing a racial hierarchy that places Indigenous peoples at the 
bottom $^{14}$. Undoubtedly, such an analysis will reveal that, despite being under immense pressure to abide by the rules of cultural fundamentalism and authenticity, Native youth, such as those in this study, also display significant resistance to doing so.

14 The results of a 2006 on-line survey and focus groups by the John Humphrey Centre for Peace and Human Rights show that racial stereotyping and discrimination remain serious human rights issues in Edmonton and that these issues have detrimental effects on quality of life: "Focus group consultations express the sentiment that there is an invisible hierarchy of racism in both Canada and Edmonton, with Aboriginals at the bottom; in other words, Aboriginals receive the most intense and frequent racism." (Canadian Heritage, 2007, p. 12)

[Type text] 


\section{References}

Angrosino, M. \& Mays de Pérez, K. (2003). Rethinking observation: from method to context. In N. Denzin and Y. Lincoln (Eds.), Collecting and Interpreting Qualitative Materials, (pp. 107-154). Thousand Oaks: Sage Publications.

Barman, J. (1986/2003). Separate and unequal: Indian and White girls in All Hallows School, 1884-1920, In J. Barman, Y. Hebert \& D. McCaskill (Eds.), Indian Education in Canada, The Legacy, (Vol. 1, pp. 110-31). Vancouver: University of British Columbia Press.

Barnhardt, R. \& Kawagley, A.O. (2005). Indigenous knowledge systems and Alaska Native ways of knowing. Anthropology and Education Quarterly, March 2005, 36(1), 8-23.

Belanger, Y., Barron, L., McKay-Turnbull, C. \& Mills, M. (2003). Urban Aboriginal youth in Winnipeg: Culture and identity formation in cities. Winnipeg: Canadian Heritage.

Berkhofer, R. F. (1978). White Conceptions of Indians. In W.E. Washburn (Ed.), Handbook of North American Indians, (Vol. 4, pp. 522-547). Washington: Smithsonian Institution Press.

Bird, E. S. (1996). Introduction: Constructing the Indian, 1830's-1990's. In S.E. Bird (Ed.), Dressing in Feathers: The Construction of the Indian in American Popular Culture (pp. 1-12). Boulder, CO: Westview Press.

Brasfield, (2009). Polar bears and fireweed. In Canadian Institute for Health Information, (Ed.), Mentally Healthy Communities: Aboriginal Perspectives. Ottawa: Canadian Institute for Health Information. Retrieved May 05, 2010, from http://secure.cihi.ca/cihiweb/products/mentally_healthy_communities_aboriginal_ perspectives_e.pdf

Brayboy, B.M.J. (2004). Hiding in the ivy: American Indian students and visibility in elite educational settings. Harvard Educational Review, 74 (2), 125-152.

Canadian Heritage (2007). Building a human rights city: Edmonton's progress and road ahead. The Human Rights City Edmonton Project and John Humphrey Centre for Peace and Human Rights, December 2007. Edmonton, AB.

Retrieved November 5, 2008, from http://www.jhcentre.org/dnn/Publications/tabid/57/Default.aspx

Dei, G.J. (2007). Speaking race: Silence, salience, and the politics of anti-racist scholarship. In S.P. Hier \& B.S. Bolaria, Race and racism in $21^{\text {st }}$ century Canada: Continuity, complexity, and change, (pp. 53-66). Peterborough, ON: Broadview Press.

Deloria Jr., V. (2004). Philosophy and the tribal peoples. In A. Waters (Ed.), American Indian thought, (pp. 3-11). Malden: Blackwell Publishing.

Denzin, N.K., \& Lincoln, Y.S. (2003). Introduction: The discipline and practice of qualitative research. In N.K. Denzin \& Y.S. Lincoln (Eds.), The Handbook of Qualitative Research (2 ${ }^{\text {nd }}$ ed., pp. 1-46). Thousand Oaks, CA: Sage Publications.

Deyhle, D. (1995). Navajo youth and Anglo racism: Cultural integrity and resistance. Harvard Educational Review. 65(3), 403-444.

Deyhle, D. (1998). From break dancing to heavy metal: Navajo youth, resistance, and identity. Youth \& Society, 30(1), 3-31.

[Type text] 
Deyhle, D. \& McCarty, T.L. (2007). Beatrice Medicine and the anthropology of education: Legacy and vision for critical race theory/critical language research and praxis. Anthropology and Education Quarterly, 38(3), 209-220.

Dillabough, J., Kennelly, J., and Wang, G. (2005). "Ginas," "thugs," and "gangstas": Young people's struggles to "become somebody" in working-class urban Canada. Journal of Curriculum Theorizing. 21(3), 83-108.

Duran, B. (1996). Indigenous versus colonial discourse: Alcohol and American Indian identity. In S.E. Bird (Ed.), Dressing in Feathers: The Construction of the Indian in American Popular Culture (pp. 1-12). Boulder, CO: Westview Press.

Enironics Institute (2010). Urban Aboriginal Peoples Survey - Main Report. Retrieved May 05, 2010, from http://uaps.ca/wp-content/uploads/2010/04/UAPS-FULL-REPORT.pdf

Fixico, D. (2003). The American Indian mind in a linear world: American Indian studies \& traditional knowledge. New York: Routledge.

Francis, D. (1992). The Imaginary Indian: the image of the Indian in Canadian culture. Vancouver: Arsenal Pulp Press.

Friedel, T.L. (2010). Finding a place for race at the policy table: Broadening the Indigenous education discourse in Canada. Aboriginal Governance - Policy Research Paper Series. Ottawa: Institute on Governance. Retrieved May 05, 2010, from http://iog.ca/sites/iog/files/content_files/2-Friedel_paper.pdf

Furniss, E. (1999). Burden of history: Colonialism and the frontier myth in a rural Canadian community. Vancouver: University of British Columbia Press.

Green, J. (2004). Cultural and ethnic fundamentalism: Identity, liberation and oppression. In C. Schick, J. Jaffe \& A.M. Watkinson (Eds.), Contesting fundamentalisms, (pp. 19-34). Halifax, Nova Scotia: Fernwood.

Gruenewald, D. (2003). Foundations of place: A multidisciplinary framework for placeconscious education. American Educational Research Journal, 40(3), 619-654.

Harper, D. (2002). Talking about pictures: A case for photo elicitation. Visual Studies, 17 (1), 13-26,

Hermes, M. (2005). Complicating discontinuity: What about poverty? Curriculum Inquiry, 35(1), 9-26.

Hitchens, J. (1994). Critical implications of Franz Boas' theory and methodology. Dialectical Anthropology, 19 (2-3), 237-253.

hooks, b. (1992). The oppositional gaze: Black female spectators. In Black looks: Race and representation, (pp. 115-131). Boston: South End Press.

Kaomea, J. (2000). A curriculum of aloha: Colonialism and tourism in Hawai 'i's elementary textbooks. Curriculum inquiry, 30(3), 319-344.

Kawagley, A.O. \& Barnhardt, R. (1999). Education Indigenous to place: Western science meets native reality. In G.A. Smith \& D.R. Williams (Eds.), Ecological education in Action: On weaving education, culture and the environment, (pp. 117-140). New York: SUNY Press.

King, T. (2003). The truth about stories: A Native narrative. Toronto: House of Anansi Press.

Kuokkanen, R. (2007). Reshaping the university: Responsibility, Indigenous episteme, and the logic of the gift. Vancouver: University of British Columbia Press.

[Type text] 
Ladson-Billings, G. (2003). Racialized discourses and ethnic epistemologies. In N. Denzin \& Y. Lincoln (Eds.), Handbook of qualitative research, $\left(3^{\text {rd }}\right.$ ed., pp. 279302). Thousand Oaks, CA: Sage Publications.

Lawrence, B. (2003). Gender, race, and the regulation of Native identity in Canada and the United States: An overview. Hypatia, 18(2), 3-31.

Ledlow, S. (1992). Is cultural discontinuity an adequate explanation for dropping out? Journal of American Indian Education, 31(3), 21-36.

MacKay, (2005). The city as home: The sense of belonging among Aboriginal youth in Saskatoon. Bridges and Foundations Project on Urban Aboriginal Housing. Retrieved January 19, 2008, from http://www.bridgesandfoundations.usask.ca/

Mackey, E. (1999/2002). The house of difference: cultural politics and national identity in Canada. Toronto, ON: University of Toronto Press.

Marker, M. (2004/05). It was two different times of the day, but in the same place: Coast Salish high school experience in the 1970's. BC Studies, 144, 91-113.

McCarty, T. Romero, M. E. \& Zepeda, O. (2006). Reclaiming the gift: Indigenous youth counter-narratives on Native language loss and revitalization. American Indian Quarterly, 30 (1 \& 2), pp. 28-48.

Miller, J.R. (1996). Shingwauk's vision: A history of Native residential schools. Toronto, ON: University of Toronto Press.

Moreton-Robinson, A. (2000). Talkin' up the White woman: Indigenous women and feminism. St. Lucia, Queensland: University of Queensland Press.

Omi, M. \& Winant, H. (2005). The theoretical status of the concept of race. In C. McCarthy, W. Crichlow, G. Dimitriadis, \& N. Dolby (Eds.), Race, Identity and Representation in Education ( $2^{\text {nd }}$ ed., pp. 3-12). New York: Routledge.

Parker, L., \& Lynn, M. (2002). What's race got to do with it? Critical race theory's conflicts with and connections to qualitative research and epistemology. Qualitative Inquiry, 8(1), 7-22.

Raibmon, P. (2005). Authentic Indians: Episodes of encounter from the late-nineteenth century Northwest Coast. Durham, North Carolina: Duke University Press.

Razack, S. (1998). Looking White People In The Eye: gender, race, and culture in courtrooms and classrooms. Toronto: University of Toronto Press.

Royal Commission on Aboriginal Peoples (1996). People to people, nation to nation: Highlights from the report the Royal Commission on Aboriginal Peoples (No. Z1-1991/1-6E). Ottawa: Minister of Supply and Services Canada.

Retrieved June 09, 2006, from http://www.ainc-inac.gc.ca/ch/rcap/index_e.html

Schick C. \& St. Denis, V. (2005). Troubling nationalist discourses in anti-racist curricular planning. Canadian Journal of Education, 28(3), pp. 295-317.

Smith, L.T. (2005). Building a research agenda for Indigenous epistemologies and education. Anthropology and Education Quarterly, 36 (1), pp. 93-96.

St. Denis, V. (2004). Real Indians: Cultural revitalization and fundamentalism in Aboriginal education. In C. Schick, J. Jaffe \& A.M. Watkinson (Eds.), Contesting fundamentalisms, (pp. 35-47). Halifax, Nova Scotia: Fernwood.

St. Denis, V. (2007). Uniting Aboriginal education with anti-racist education: Building alliances across cultural and racial politics. Canadian Journal of Education, 30(4), 1068-1092.

[Type text] 
St. Denis, V. \& Hampton, E. (2002, November). Literature review on racism and the effects on Aboriginal education. Ottawa, Ontario: Minister's Working Group on Education. Retrieved January, 2008, from www.sfu.ca/mpp/aboriginal/colloquium/pdf/Racism_and_Abo_Education.pdf

Statistics Canada (2008). Aboriginal Peoples in Canada in 2006: Inuit, Métis and First Nations, 2006. (No. 97-558-XIE). Ottawa: Minister of Technology.

Retrieved September 08, 12, 2008, from

http://www.statcan.ca/bsolc/english/bsolc?catno=97-558-X

Trask, H.K. (1996). Feminism and the Indigenous Hawaiian nationalism. Journal of Women in Culture and Society, 21(4), 906-916.

Young, I.M. (1990). Justice and the Politics of Difference. Princeton, NJ: Princeton University Press.

[Type text] 